\title{
Surgical management of sarcoma in adolescent and young adult patients
}

Kazuhiko Hashimoto ( $\sim$ hazzhiko@med.kindai.ac.jp)

https://orcid.org/0000-0002-8332-0063

Shunji Nishimura

Kindai University Hospital

Naohiro Oka

Kindai University Hospital

Masao Akagi

Kindai University Hospital

\section{Research note}

Keywords: sarcoma, surgery, adolescent and young adult, prognosis

Posted Date: April 27th, 2020

DOl: https://doi.org/10.21203/rs.3.rs-23083/v1

License: @ (i) This work is licensed under a Creative Commons Attribution 4.0 International License. Read Full License

Version of Record: A version of this preprint was published at BMC Research Notes on May 26th, 2020. See the published version at https://doi.org/10.1186/s13104-020-05107-0. 


\section{Abstract}

Objective To examine the clinical features and outcomes of adolescent and young adult sarcoma patients who underwent surgical management and clarify important factors associated with prognosis. We reviewed 18 young adult sarcoma patients sarcoma patients treated surgically in our hospital. The tumor site, histology, grade, stage, and American Society of Anesthesiologists-Physical Status before surgery, operation time, intraoperative blood loss, surgical margin, local recurrence, metastasis, and final outcome were investigated. The 3-year survival rate was also calculated. We compared survival based on age, grade, operation time, and intraoperative blood loss and surveyed features of cases of poor outcomes.

Results The 3-year survival rate was $61.3 \%$. There was no significant difference in survival based on age, grade, operation time, or intraoperative blood loss. Three of five patients who died of the disease had stage $\geq$ IV at diagnosis. All patients with inadequate surgical margins developed recurrence and all those with an American Society of Anesthesiologists-Physical Status $\geq 2$ died. Patients with a late-stage sarcomas, inadequate tumor margin, or high American Society of Anesthesiologists-Physical Status score had poor prognosis. To achieve a favorable outcome in adolescent and young adult sarcoma patients, early detection and obtaining an adequate surgical margin are important.

\section{Introduction}

Sarcoma is a rare malignancy developing in non-epithelial tissues such as the fat, muscle, and bone [1]. In Japan, the annual incidences of bone and soft tissue sarcomas are 1 and 3 per 100,000 people per year, respectively [2, 3]. Although the incidence account to only $1-2 \%$ that of cancers such as colorectal, stomach, and lung, there are more than 50 histological types of sarcomas, and the malignancy varies [4]. Furthermore, sarcoma has no age prevalence [5]. Recently, oncologists have paid greater attention to adolescent and young adult (AYA) patients because AYAs with cancer require special social support and psychological care [6] and the incidence of cancer among AYA patients has increased [7]. The number of sarcomas in the AYA age group has also increased [8].

According to previous reports, the 5-year survival rate of sarcoma is around 60-70\% [4]. The treatment strategy for and prognosis of sarcomas have improved over the past few decades [9]. However, there have been no recent improvements in treatment, and the survival rate has plateaued [9]. Additionally, the prognosis in AYA sarcoma patients has not improved because AYA sarcoma cases are rare and we lack clinical data [10]. Recently, we described the clinical features and outcomes of AYA sarcomas in our hospital [11]. In the current study, we analyzed the data of sarcomas in AYA patients treated surgically and identified the patients that had poor prognosis to determine optimal surgical treatment approaches.

\section{Patients And Methods Patients and Methods}

We reviewed 18 sarcoma cases (10 in the soft tissue and 8 in the bone) treated surgically in our institute between March 2009 and May 2018 . Records of eight male patients and ten female patients aged 15-39 years (mean, 33 years) were reviewed retrospectively. Tumor site, histology, grade, stage, European Society for Medical Oncology Guidelines Performance Status (ECOG-PS), American Society of Anesthesiologists-Physical Status (ASA-PS) before surgery, surgical treatment methods, operation time, intraoperative blood loss, surgical margin, local recurrence, metastasis, and outcome were investigated. Using previously described methods, surgical margins were classified as adequate, inadequate, or intralesional [12] and R0, R1, or R2 [13]. R1 and R2 margins were those in which residual tumor was detectable microscopically and macroscopically, respectively. We also surveyed features of poor outcomes of the dead of disease (DOD) cases.

\section{Statistical analysis}

The Statmate 5.01 software package was used to assess the 3-year survival rates. The patients' 3-year survival rates were calculated using the Kaplan-Meier method and differences were assessed using the log-rank test. $\mathrm{P}<0.05$ was considered to indicate a statistically significant difference.

This study was approved by the Ethics Committee of Kindai University Hospital (approval no.: 31-153) (Osaka, Japan). All patients also provided written informed consent for participation in this retrospective study.

\section{Results}

Patient characteristics

The present retrospective study comprised 18 patients ( 8 men and 10 women) with sarcoma who underwent surgery in our department (Table 1 ). Among patients with bone tumors, the tumor site was the femur in three patients, tibia in three, fibula in one, and humerus in one. In terms of histology, six had osteosarcoma and two had chondrosarcoma. Six patients had histological high-grade tumors and two had low-grade tumors. One, three, two, and one patient had stage IB, IIA, IIB, and IVB disease, respectively. Five patients had an ECOG-PS score of 0, two had an ECOG-PS score of 1, and one had an ECOG-PS score of 2. Seven patients had an ASA-PS score of 1 , and one had an ASA-PS score of 2. 
Table 1

Clinical features of patients with bone and soft tissue sarcoma in AYA

\begin{tabular}{|c|c|c|c|c|c|c|c|c|c|c|c|c|c|}
\hline $\begin{array}{l}\text { Patient } \\
\text { no. }\end{array}$ & Age/Sex & $\begin{array}{l}\text { Bone } \\
\text { or } \\
\text { soft } \\
\text { tissue }\end{array}$ & Site & Histology & Grade & $\begin{array}{l}\text { ECOG- } \\
\text { PS }\end{array}$ & $\begin{array}{l}\text { ASA- } \\
\text { PS }\end{array}$ & Chemotherapy & Treatment & $\begin{array}{l}\text { Op. } \\
\text { time } \\
\text { (min) }\end{array}$ & $\begin{array}{l}\text { Blood } \\
\text { loss } \\
(\mathrm{mL})\end{array}$ & Margin & $\begin{array}{l}\text { Lo } \\
\text { rec }\end{array}$ \\
\hline 1 & $17 / \mathrm{M}$ & Bone & Tibia & $\begin{array}{l}\text { Osteosarcoma } \\
\text { (Conventional) }\end{array}$ & High & 1 & 1 & NECO-95J & CT, WR & 160 & 500 & $\mathrm{R} 1$ & + \\
\hline 2 & $36 / F$ & Bone & Tibia & $\begin{array}{l}\text { Osteosarcoma } \\
\text { (Conventional) }\end{array}$ & High & 0 & 1 & NECO-95J & Curettage & 108 & 10 & - & + \\
\hline 3 & $39 / \mathrm{M}$ & Bone & Femur & $\begin{array}{l}\text { Chondrosarcoma } \\
\text { grade I }\end{array}$ & Low & 0 & 1 & - & Curettage & 240 & 860 & - & - \\
\hline 4 & $33 / \mathrm{M}$ & Bone & Femur & $\begin{array}{l}\text { Chondrosarcoma } \\
\text { grade II }\end{array}$ & Low & 0 & 1 & - & Curettage & 120 & 160 & - & - \\
\hline 5 & $15 / F$ & Bone & Femur & $\begin{array}{l}\text { Osteosarcoma } \\
\text { (Osteoblastic) }\end{array}$ & High & 2 & 1 & NECO-95J & CT, WR & 215 & 521 & RO & - \\
\hline 6 & $36 / F$ & Bone & Tibia & $\begin{array}{l}\text { Osteosarcoma } \\
\text { (Chondroblastic) }\end{array}$ & High & 0 & 1 & NECO-95J & CT, WR & 245 & 250 & RO & - \\
\hline 7 & $27 / M$ & Bone & Fibula & $\begin{array}{l}\text { Osteosarcoma } \\
\text { (Conventional) }\end{array}$ & High & 0 & 1 & NECO-95J & CT, WR & 500 & 392 & Ro & - \\
\hline 8 & $29 / F$ & Bone & Humerus & $\begin{array}{l}\text { Osteosarcoma } \\
\text { (Conventional) }\end{array}$ & High & 1 & 2 & NECO-95J & CT, WR & 295 & 571 & RO & - \\
\hline 9 & $35 / F$ & $\begin{array}{l}\text { Soft } \\
\text { tissue }\end{array}$ & Thigh & Leiomyosarcoma & High & 1 & 3 & - & WR & 245 & 418 & R0 & - \\
\hline 10 & $32 / \mathrm{M}$ & $\begin{array}{l}\text { Soft } \\
\text { tissue }\end{array}$ & Buttock & Ewing & High & 1 & 2 & VAdCA-IE & CT, WR & 140 & 615 & RO & - \\
\hline 11 & $35 / \mathrm{M}$ & $\begin{array}{l}\text { Soft } \\
\text { tissue }\end{array}$ & Thigh & $\begin{array}{l}\text { Synovial } \\
\text { sarcoma }\end{array}$ & High & 0 & 1 & $\begin{array}{l}\text { IA } \times 3 \text { (Post } \\
\text { surgery) }\end{array}$ & $\mathrm{CT}, \mathrm{WR}$ & 364 & 282 & $\mathrm{R} 1$ & + \\
\hline 12 & $27 / F$ & $\begin{array}{l}\text { Soft } \\
\text { tissue }\end{array}$ & Abdomen & $\begin{array}{l}\text { Synovial } \\
\text { sarcoma }\end{array}$ & High & 0 & 1 & $\begin{array}{l}\text { IA } \times 3 \text { (Post } \\
\text { surgery) }\end{array}$ & CT, WR & 102 & 10 & RO & - \\
\hline 13 & $36 / F$ & $\begin{array}{l}\text { Soft } \\
\text { tissue }\end{array}$ & $\begin{array}{l}\text { Upper } \\
\text { extremity }\end{array}$ & Liposarcoma & High & 1 & 1 & - & WR & 95 & 10 & RO & - \\
\hline 14 & $26 / M$ & $\begin{array}{l}\text { Soft } \\
\text { tissue }\end{array}$ & Thigh & $\begin{array}{l}\text { Myxoid } \\
\text { liposarcoma }\end{array}$ & Low & 0 & 1 & - & WR & 140 & 935 & RO & - \\
\hline 15 & $34 / F$ & $\begin{array}{l}\text { Soft } \\
\text { tissue }\end{array}$ & Thigh & $\begin{array}{l}\text { Myxoid } \\
\text { liposarcoma }\end{array}$ & High & 0 & 1 & $\begin{array}{l}\text { IA 3(Pre- } \\
\text { surgery)/2 } \\
\text { (Post surgery) }\end{array}$ & CT, WR & 145 & 138 & $\mathrm{R} 1$ & + \\
\hline 16 & $33 / F$ & $\begin{array}{l}\text { Soft } \\
\text { tissue }\end{array}$ & Thigh & $\begin{array}{l}\text { Synovial } \\
\text { sarcoma }\end{array}$ & High & 0 & 1 & $\begin{array}{l}\text { IA 3(Pre- } \\
\text { surgery)/2 } \\
\text { (Post surgery) }\end{array}$ & CT, WR & 237 & 235 & R0 & - \\
\hline 17 & $37 / M$ & $\begin{array}{l}\text { Soft } \\
\text { tissue }\end{array}$ & Buttock & $\begin{array}{l}\text { Myxoid } \\
\text { liposarcoma }\end{array}$ & High & 0 & 1 & $\begin{array}{l}\text { IA } \times 3 \text { (Post } \\
\text { surgery) }\end{array}$ & CT, WR & 103 & 196 & RO & - \\
\hline 18 & $32 / F$ & $\begin{array}{l}\text { Soft } \\
\text { tissue }\end{array}$ & Groin & $\begin{array}{l}\text { Myxoid } \\
\text { liposarcoma }\end{array}$ & High & 0 & 1 & $\begin{array}{l}\text { IA } \times 3 \text { (Post } \\
\text { surgery) }\end{array}$ & WR, RT & 191 & 50 & $\mathrm{RO}$ & - \\
\hline
\end{tabular}

y: years, F: female, M: male, CT: chemotherapy, WR: wide resection, NECO: Neoadjuvant Chemotherapy for Osteosarcoma, IA: ifosfamide and doxorubicin, Mc continuously disease-free, ECOG-PS: European Society for Medical Oncology Guidelines Performance Status, ASA-PS: American Society of Anesthesiologists VAdCA-IE: vincristin, actinomycinD, doxorubicin, cyclophosphamide, ifosfamide, etoposide, NED: no evidence of disease

Among patients with soft tissue tumors, the tumor site was the thigh in five patients, buttock in two, upper extremity in one, abdomen in one, and groin in one.

In terms of histology, five had liposarcoma, three had synovial sarcoma, one had Ewing sarcoma, and one had leiomyosarcoma. Nine patients had histological high-grade tumors, and one had a low-grade tumor. One, two, three, two, and two patients had stage I, II, IIIA, IIIB, and IVB disease, respectively. Seven patients had an ECOG-PS score of 0 , and three patients had an ECOG-PS score of 1. Eight patients had an ASA-PS score of 1, one had an ASA-PS score of 2, and one had an APA-PS score of 3 .

Treatment

Five patients with bone tumors received wide resection with neoadjuvant chemotherapy (NECO-95J) [14], and three received curettage resection. Of the patients who received wide resection, four achieved R0 resection and one achieved R1 resection. Six patients with soft tissue tumors received wide resection with neoadjuvant chemotherapy (five patients: $5 \mathrm{~g} / \mathrm{m}^{2}$ ifosfamide and $75 \mathrm{mg} / \mathrm{m}^{2}$ doxorubicin [15], and one patient: $1.5 \mathrm{mg} / \mathrm{m}^{2}$ vincristine, $37.5 \mathrm{mg} / \mathrm{m}^{2}$ doxorubicin, $1,200 \mathrm{mg} / \mathrm{m}^{2}$ cyclophosphamide, $1.8 \mathrm{~g} / \mathrm{m}^{2}$ ifosfamide, and $100 \mathrm{mg} / \mathrm{m}^{2}$ etoposide for Ewing sarcoma [16]). Four patients received wide resection without any preoperative therapy, although one received postoperative radiation therapy (60 Gy: $2 \mathrm{~Gy} /$ day, 5 days/week). Eight of the patients with soft tissue tumors achieved R0 resection and two achieved R1 resection. 
The mean operation time for all patients was 175.5 minutes (range, 95-500 minutes). The mean operation time for patients with bone tumors was 142.5 minutes (range, 95-364 minutes), and the mean operation time for patients with soft tissue tumors was 227.5 minutes (range, 108-500 minutes). There was no significant difference in the operation time between patients with bone tumors and those with soft tissue tumors ( $p=0.11$; Student's t-test). The mean intraoperative blood loss in all patients was $266 \mathrm{~mL}$ (range, 10-935 mL). The mean intraoperative blood loss in patients with bone tumors was $446 \mathrm{~mL}$ (range, 10-860 mL), and the mean intraoperative blood loss in patients with soft tissue tumors was $215.5 \mathrm{~mL}$ (range: $10-935 \mathrm{~mL}$ ). There was no significant difference in intraoperative blood loss between patients with bone tumors and those with soft tissue tumors $(p=0.11$; Student's t-test).

Outcomes

We followed up patients for 8-162 (mean: 44) months. Two patients with bone tumors and two with soft tissue tumors developed local recurrence. Two patients with bone tumors and three with soft tissue tumors developed distant metastasis. Among patients with bone tumors, five were continuously diseasefree (CDF), one had no evidence of disease (NED), and two were DOD. Among patients with soft tissue tumors, five were CDF, two had NED, and three were DOD. The 3-year survival rate of all of the patients was $61.3 \%$ (Fig. 1A). The 3 -year survival rate of younger patients $(<33$ years) was $56 \%$ and that of older patients (>33 years) was $60 \%$. There was no significant difference in the 3 -year survival rate based on age $(p=0.46$, Fig. 1B). The 3-year survival rate among patients with high-grade sarcoma was $42.8 \%$ and that among patients with low-grade sarcoma was $100 \%$. There was no significant difference in the 3 -year survival rate based on sarcoma grade $(p=0.08$, Fig. $1 \mathrm{C})$. The 3-year survival rate among patients with a longer operation time $(>175.5$ minutes) was $65.6 \%$ and that of patients with a shorter operation time (< 175.5 minutes) was $58.3 \%$; there was no significant difference in the 3 -year survival rate based on operation time ( $p=0.82$, Fig. $2 A)$. The 3-year survival rate of patients with a larger intraoperative blood loss $(>215.5 \mathrm{~mL})$ was $51.8 \%$ and that of patients with a smaller intraoperative blood loss $(<215.5 \mathrm{~mL})$ was $75.0 \%$; there was no significant difference in the 3-year survival rate based on intraoperative blood loss $(p=$ 0.24, Fig. 2B).

We also surveyed features of the DOD cases. Three of five $(60 \%)$ patients in the DOD group had $\geq$ stage IV disease. All patients who had R1 margins developed recurrence. Moreover, all patients with an ASA-PS $\geq 2$ died.

\section{Discussion}

It is vital to identify the optimal treatment of sarcomas in AYA patients. However, there is still little evidence, and protocols on how to treat sarcomas in AYA patients have not been clarified in detail. In the current study, we reviewed sarcoma patients treated surgically in our hospital and analyzed which types of patients had poor outcomes. Patients with late-stage sarcomas, inadequate tumor margin, or a high ASA-PS score had a poor prognosis.

The 5-year survival rate in AYA sarcoma patients is approximately 70\% [10, 17], although prognoses in AYA patients may vary depending on age [17]. Our previous study showed that the 5-year survival rate of elderly sarcoma patients was $86 \%$ [18]. In the current study, the 3 -year survival rate was poorer (61.36\%) than those previously reported [18] and that of elderly patients in our hospital. There was also no significant difference in survival rates based on age among these AYA patients. These findings suggest that the AYA generation itself may be a poor prognostic factor.

In general, high-grade sarcoma has a poorer prognosis than low-grade sarcoma [19]. Aggressive high-grade malignancies often arise in AYAs [20]. Additionally, late-stage sarcomas have a poorer prognosis than early-stage sarcomas [21]. Approximately $80 \%$ of AYA sarcoma patients are diagnosed at an early stage [22]. In the current study, we found that AYA sarcoma patients with late-stage sarcomas had a poorer prognosis than those with early-stage sarcomas. These findings suggest that early diagnosis is necessary to obtain a favorable outcome for AYA sarcoma patients.

A Canadian registry showed that the mean operation time for sarcoma was 4 hours, and an operation time $>5$ hours increased the likelihood of reoperation because of wound complications, such as infection [23]. In elderly sarcoma patients, the mean operation time is 114.7 minutes and the mean blood loss is $160.7 \mathrm{~mL}$ [11]. Additionally, a previous study showed that the infection rate after surgical treatment for sarcomas was 23.3\% [24]. In the current study, there was no reoperation and no patients developed infection; however, the operation time and intraoperative blood loss were longer and larger, respectively, than those previously reported for elderly sarcoma patients [18].

Achieving a wide margin is important to obtain favorable outcomes $[18,25,26]$. In the current study, all patients with inadequate margins after surgical treatment experienced recurrence. These findings suggest that achieving an adequate surgical margin is important in the surgical management of AYA sarcoma patients to obtain a favorable prognosis.

The ASA-PS is a general condition classification by the American Society of Anesthesiologists [27]. Recently, Iwai et al. reported that the prognosis of elderly sarcoma patients is correlated with ASA-PS before surgery [28]. In the current study, all patients with an ASA-PS $\geq 2$ died. These findings suggest that the ASAPS may also influence the prognosis or outcome of AYA sarcoma patients undergoing surgical treatment.

\section{Limitations}

Our study had some limitations. First, the number of patients was small. Second, the included tumors were considerably diverse. Third, we were unable to compare the outcomes of these patients to those of younger patients with sarcoma. A future comparative study has been planned to address this point.

In summary, we assessed the clinical features and outcomes of AYA sarcoma patients treated surgically in our hospital. Early detection and appropriate surgical margins are of utmost importance for obtaining a good prognosis in the management of AYA sarcoma patients.

\section{Abbreviations}


adolescent and young adult

ECOG

European Society for Medical Oncology Guidelines

ASA-PS

Anesthesiologists-Physical Status

\section{Declarations}

\section{Ethics approval:}

This study was approved by the Ethics Committee of Kindai University Hospital (approval no.: 31-153) (Osaka, Japan). All patients also provided written informed consent for the participation of this retrospective study.

\section{Consent for publish}

All patients also provided written informed consent for the publication of this retrospective study.

\section{Availability of data and material}

All data generated or analyzed during this study are included in this published article.

\section{Conflicts of interest/Competing interests}

The Authors declare that there is no conflict of interest.

\section{Funding:}

No funding was received.

\section{Authors' contributions}

$\mathrm{KH}, \mathrm{SN}, \mathrm{NO}$, and MA performed the study, and collated, analyzed and interpreted the data. $\mathrm{KH}, \mathrm{SN}$, and MA wrote the manuscript.

\section{Acknowledgement}

The authors would like to thank Editage (www.editage.jp) for English language editing

\section{References}

1. Soleymani T, Tyler Hollmig S. Conception and management of a poorly 1. Soleymani T, Tyler Hollmig S. Conception and management of a poorly understood spectrum of dermatologic neoplasms: atypical fibroxanthoma, pleomorphic dermal sarcoma, and undifferentiated pleomorphic sarcoma. Curr Treat Options Oncol. 2017;18(8):50.

2. Tanaka K, Mizusawa J, Naka N, Kawai A, Katagiri H, Hiruma T, et al. Ten-year follow-up results of perioperative chemotherapy with doxorubicin and ifosfamide for high-grade soft-tissue sarcoma of the extremities: Japan Clinical Oncology Group study JCOG0304. BMC Cancer. 2019;19(1):890.

3. Aiba H, Yamada S, Mizutani J, Yamamoto N, Okamoto H, Hayashi K, et al. Clinical outcomes of radio-hyperthermo-chemotherapy for soft tissue sarcoma compared to a soft tissue sarcoma registry in Japan: a retrospective matched-pair cohort study. Cancer Med. 2018;7(4):1560-71.

4. Mattei JC, Bouvier-Labit C, Barets D, Macagno N, Chocry M, Chibon F, et al. Pan aurora kinase inhibitor: a promising targeted-therapy in dedifferentiated liposarcomas with differential efficiency depending on sarcoma molecular profile. Cancers (Basel). 2020;12(3):E583.

5. Ceyssens S, Stroobants S. Sarcoma Methods Mol Biol. 2011;727:191-203.

6. Smith AW, Keegan T, Hamilton A, Lynch C, Wu XC, Schwartz SM, et al. Understanding care and outcomes in adolescents and young adult with Cancer: A review of the AYA HOPE study. Pediatr Blood Cancer. 2019;66(1):e27486.

7. Gupta S, Harper A, Ruan Y, Barr R, Frazier AL, Ferlay J, et al. International trends in the incidence of cancer among adolescents and young adults. J Natl Cancer Inst [internet]. Available from: https://academic.oup.com/jnci/advance-article-abstract/doi/10.1093/jnci/djaa007/5713519? redirectedFrom=fulltext Article [Epub ahead of print]

8. Katanoda K, Shibata A, Matsuda T, Hori M, Nakata K, Narita Y, et al. Childhood, adolescent and young adult cancer incidence in Japan in 2009-2011. Jpn J Clin Oncol. 2017;47(8):762-71.

9. Friebele JC, Peck J, Pan X, Abdel-Rasoul M, Mayerson JL. Osteosarcoma: A meta-analysis and review of the literature. Am J Orthop. 2015;44(12):547-53.

10. Fukushima T, Ogura K, Akiyama T, Takeshita K, Kawai A. Descriptive epidemiology and outcomes of bone sarcomas in adolescent and young adult patients in Japan. BMC Musculoskelet Disord. 2018;19(1):297. 
11. Hashimoto K, Nishimura S, Oka N, Akagi M. Clinical features and outcomes of primary bone and soft tissue sarcomas in adolescents and young adults. Mol Clin Oncol. 2020;12(4):358-64.

12. Kawaguchi N, Ahmed AR, Matsumoto S, Manabe J, Matsushita Y. The concept of curative margin in surgery for bone and soft tissue sarcoma. Clin Orthop Relat Res. 2004;419:165-72.

13. Gundle KR, Kafchinski L, Gupta S, Griffin AM, Dickson BC, Chung PW, et al. Analysis of margin classification systems for assessing the risk of local recurrence after soft tissue sarcoma resection. J Clin Oncol. 2018;36(7):704-09.

14. Iwamoto Y, Tanaka K, Isu K, Kawai A, Tatezaki S, Ishii T, et al. Multiinstitutional phase II study of neoadjuvant chemotherapy for osteosarcoma (NECO study) in Japan: NECO-93J and NECO-95J. J Orthop Sci. 2009;14(4):397-404.

15. Woll PJ, Reichardt P, Le Cesne A, Bonvalot S, Azzarelli A, Hoekstra HJ, et al. Adjuvant chemotherapy with doxorubicin, ifosfamide, and lenograstim for resected soft-tissue sarcoma (EORTC 62931): a multicentre randomised controlled trial. Lancet Oncol. 2012;13(10):1045-54.

16. Chin M, Yokoyama R, Sumi M, Okita H, Kawai A, Hosono A, et al. Multimodal treatment including standard chemotherapy with vincristine, doxorubicin, cyclophosphamide, ifosfamide, and etoposide for the Ewing sarcoma family of tumors in Japan: Results of the Japan Ewing Sarcoma Study 04. Pediatr Blood Cancer. 2020;67(5):e28194.

17. Salem ME, Battaglin F, Goldberg RM, Puccini A, Shields AF, Arguello D, et al. Molecular analyses of left- and right-sided tumors in adolescents and young adults with colorectal cancer. Oncologist [internet]. Available from: https://theoncologist.onlinelibrary.wiley.com/doi/abs/10.1634/theoncologist.20190552 Article [Epub ahead of print].

18. Hashimoto K, Nishimura S, Hara Y, Oka N, Tanaka H, lemura S, et al. Clinical outcomes of patients with primary malignant bone and soft tissue tumor aged 65 years or older. Exp Ther Med. 2019;17(1):888-94.

19. Seagle BL, Shilpi A, Buchanan S, Goodman C, Shahabi S. Low-grade and high-grade endometrial stromal sarcoma: A National Cancer Database study. Gynecol Oncol. 2017;146(2):254-62.

20. Ferrari A, Dirksen U, Bielack S. Sarcomas of soft tissue and bone. Prog Tumor Res. 2016;43:128-41.

21. Zhang C, Guo X, Xu Y, Han X, Cai J, Wang X, et al. Lung metastases at the initial diagnosis of high-grade osteosarcoma: prevalence, risk factors and prognostic factors. A large population-based cohort study. Sao Paulo Med J. 2019;137(5):423-29.

22. Avila JC, Livingston JA, Rodriguez AM, Kirchhoff AC, Kuo YF, Kaul S. Disparities in adolescent and young adult sarcoma survival: analyses of the Texas cancer registry and the national SEER data. J Adolesc Young Adult Oncol. 2018;7(6):681-7.

23. Houdek MT, Griffin AM, Ferguson PC, Wunder JS. Morbid obesity increases the risk of postoperative wound complications, infection, and repeat surgical procedures following upper extremity limb salvage surgery for soft tissue sarcoma. Hand (N Y). 2019;14(1):114-20.

24. Elswick SM, Curiel DA, Wu P, Akhavan A, Molinar VE, Mohan AT, et al. Complications after thigh sarcoma resection. J Surg Oncol [internet]. Available from: https://onlinelibrary.wiley.com/doi/abs/10.1002/jso.25830 Article [Epub ahead of print].

25. Liu CY, Yen CC, Chen WM, Chen TH, Chen PC, Wu HT, et al. Soft tissue sarcoma of extremities: the prognostic significance of adequate surgical margins in primary operation and reoperation after recurrence. Ann Surg Oncol. 2010;17(8):2102-11.

26. Kang J, Xu M, Wang B, Yu X. Wide resection of soft tissue sarcomas after unplanned primary procedures: A long-term follow-up study. Medicine (Baltimore). 2020;99(8):e19067.

27. Hosking MP, Warner MA, Lobdell CM, Offord KP, Melton LJ. Outcomes of surgery in patients 90 years of age and older. JAMA. 1989;261(13):1909-15.

28. Iwai T, Hoshi M, Takada J, Oebisu N, Aono M, Takami M, et al. Prognostic factors for elderly patients with primary malignant bone and soft tissue tumors. Oncol Lett. 2015;10(3):1799-804.

\section{Figures}


Figure 1.
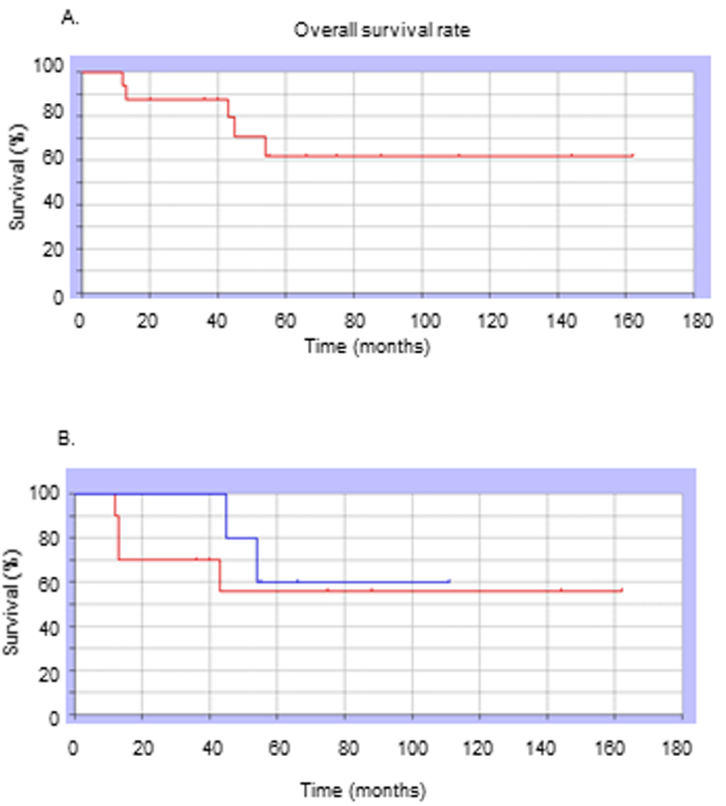

c.

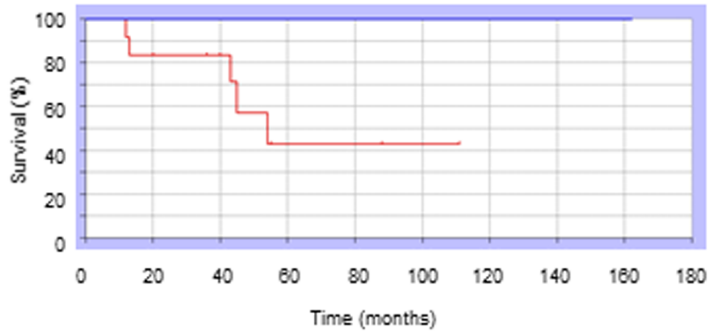

\section{Figure 1}

Figure 1A. Survival rates of the 18 patients with malignant bone or soft tissue tumors. The Kaplan-Meier method was used to generate survival curves. The 3year survival rate was $61.36 \%$. Figure 1B. Prognosis according to age. The Kaplan-Meier method was used to generate survival curves. The blue line represents the survival of younger patients ( $<33$ years). The red line represents the survival of older patients ( $\geq 33$ years). The 3 -year survival rates of the two groups were $60 \%$ and $56 \%$, respectively. There was no significant difference in the 3 -year survival rate based on age $(p=0.46)$. Figure $1 \mathrm{C}$. Prognosis according to histological grade. The Kaplan-Meier method was used to generate survival curves. The blue line represents the survival of patients with low-grade sarcomas. The red line represents the survival of patients with high-grade sarcomas. The 3 -year survival rates of the two groups were $100 \%$ and $42.8 \%$, respectively. There was no significant difference in the 3-year survival rate based on tumor grade $(p=0.08)$. 
Figure 2.
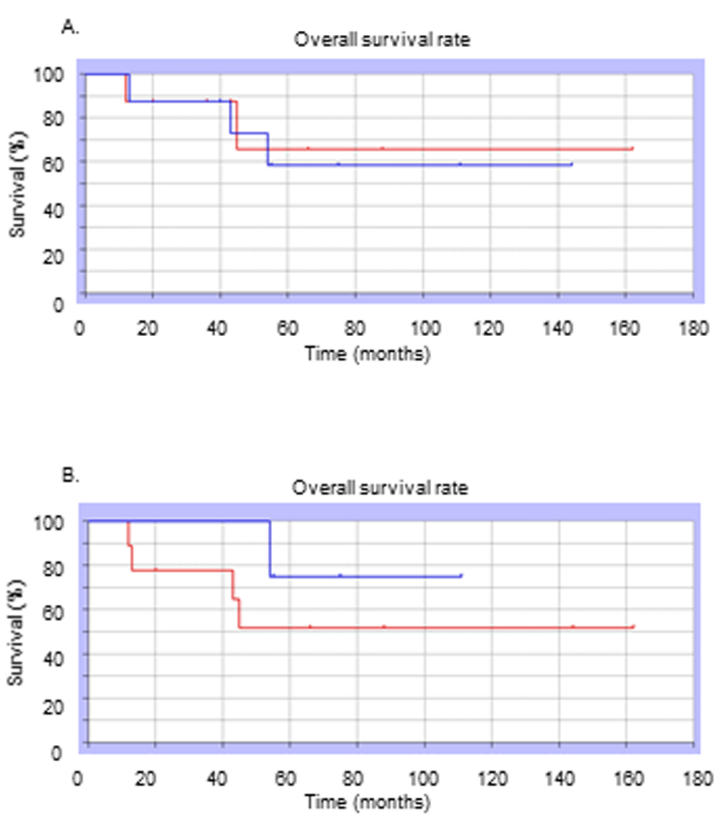

\section{Figure 2}

Figure 2A. Prognosis according to operation time. The Kaplan-Meier method was used to generate survival curves. The blue line represents the survival of patients with a longer operation time (>175.5 minutes). The red line represents the survival of patients with a shorter operation time (<175.5 minutes). The $3-$ year survival rates of the two groups were $65.6 \%$ and $58.3 \%$, respectively. There was no significant difference in the 3 -year survival rate based on operation time $(p=0.82)$. Figure 2B. Prognosis according to intraoperative blood loss. The Kaplan-Meier method was used to generate survival curves. The blue line represents survival of patients with a larger intraoperative blood loss $(>215.5 \mathrm{~mL})$. The red line represents survival of patients with a smaller intraoperative blood loss $(<215.5 \mathrm{~mL})$. The 3-year survival rates of the two groups were $75 \%$ and $51.8 \%$, respectively. There was no significant difference in the 3 -year survival rates based on intraoperative blood loss $(p=0.24)$. 